\title{
DZIEDZICTWO FILMOWE W PRAWIE UNII EUROPEJSKIEJ
}

W myśl art. 151 ust. 4 Traktatu ustanawiającego Wspólnotę Europejską, Wspólnota ma uwzględniać aspekty kulturalne w swoim działaniu na podstawie innych postanowień Traktatu, przyczyniając się w ten sposób do rozkwitu kultur państw członkowskich, poszanowania ich rożności narodowej i regionalnej, co dodatkowo podkreślać winno znaczenie wspólnego dziedzictwa kulturowego. Działania Wspólnoty zmierzają do współpracy między Państwami Członkowskimi oraz jeśli jest o niezbędnego do wspierania i uzupełniania działań tych państw m.in. w dziedzinie twórczości artystycznej i literackiej włącznie z sektorem audiowizualnym. Niewątpliwie art. 151 Traktatu ma charakter programowy, wyznacza, bowiem kierunki działań instytucji unijnych w tym zwłaszcza przedsięwzięć prawodawczych ${ }^{1}$. Treść tego przepisu oraz art. 157 Traktatu ustanawiającego Wspólnotę Europejską stała się asumptem dla wydania przez Parlament Europejski i Radę w dniu 16 listopada 2005 r. zalecenia w sprawie dziedzictwa filmowego i konkurencyjności związanych z nim działań przemysłowych 2005/865/WE².

Powodem wydania tego Zalecenia stała się także opinia Europejskiego Komitetu Ekonomiczno-Społecznego w sprawie propozycji zalecenia Parlamentu Europejskiego i Rady w sprawie dorobku filmowego oraz konkurencyjności związanej z nim działalności przemysłowej³ ${ }^{3}$ W treści tego ostatniego dokumentu znalazło się życzenie Komitetu, aby został skrócony czas między udostępnieniem filmu publiczności, a terminem przekazania obowiązkowej kopii oraz przyjęcia rozwiązań ułatwiających także przekazywanie kopii utworów kinematograficznych i audiowizualnych należących do krajowego dorobku audiowizualnego, a powstałych przed wprowadzeniem prawnego obowiązku przekazywania kopii archiwalnych na podstawie zalecenia. Komitet wskazał także, że dzieła kinematograficzne $\mathrm{i}$ audiowizualne są z jednej strony wyrobami przemysłowymi, z drugiej dobrami

* KSEnia KAKAREKO - adiunkt Katedry Prawa Mediów Uniwersytetu Warszawskiego, e-mail: ksenia.kakareko@gmail.com.

${ }^{1}$ W. Sanetra, w: A. Wróbel (red.) Traktat o funkcjonowaniu Unii Europejskiej. Komentarz, t. II, Warszawa 2012, s. 905.

2 Dz. Urz. UE L 2005, Nr 323, str. 57.

${ }^{3}$ Dz. Urz. UE C 2005, Nr 74, str. 18. 
kultury, które należy chronić, jako element wspólnego dziedzictwa europejskiego i promować jako nośnik pluralizmu. Zauważył wreszcie, że koniecznym jest wykorzystywanie potencjału ekonomicznego filmu. Podkreślono w Opinii, że przekazywanie dzieł kinematograficznych we władanie organom archiwizującym, nie wiąże się koniecznie z przekazaniem praw autorskich i pokrewnych. Przypomniano, że zgodnie z dyrektywą 2001/29/WE Parlamentu Europejskiego i Rady z 22 maja 2001 r. w sprawie harmonizacji niektórych aspektów praw autorskich i pokrewnych w społeczeństwie informacyjnym ${ }^{4}$, Państwa Członkowskie mogą przewidzieć wyjątki lub ograniczenia w odniesieniu do szczególnych czynności zwielokrotniania, dokonywanych przez ogólnodostępne biblioteki lub archiwa i niemających na celu żadnych bezpośrednich lub pośrednich korzyści gospodarczych i handlowych. Wskazano przy tym, że Komitet popiera dopuszczenie reprodukcji zdeponowanych dzieł kinematograficznych dla celów ich konserwacji. Dostrzegając problemy prawne związane z prawami autorskimi i szczególnymi przypadkami reprodukcji dokonywanej przez ogólnodostępne biblioteki lub archiwa, a także zreprodukowaniem dla celów konserwacji, zaproponowano, aby rozwiązanie tych kwestii powierzyć zespołowi ekspertów wysokiego szczebla, wskazując równocześnie, iż możliwa jest przebudowa sieci ekspertów krajowych, których opinii już zasięgano.

Podkreślono wyraźnie, że Europejski Komitet Ekonomiczno - Społeczny życzyłby sobie skrócenia okresu między udostępnieniem filmu publiczności, a terminem przekazania obowiązkowej kopii oraz przyjęcia rozwiązań ułatwiających przekazywanie kopii utworów kinematograficznych i audiowizualnych, należących do krajowego dorobku audiowizualnego, a powstałych przed wprowadzeniem prawnego obowiązku przekazywania kopii archiwalnych na podstawie zalecenia. W opinii wyrażono także przekonanie, że dzieła kinematograficzne i audiowizualne są zarówno wyrobami przemysłowymi, jak i dobrami kultury. Wskazano, że należy je chronić jako element wspólnego dziedzictwa europejskiego i promować, jako nośnik pluralizmu, ale jednocześnie wykorzystywać potencjał ekonomiczny takich dzieł. W konsekwencji zdaniem Europejskiego Komitetu Ekonomiczno - Społecznego należy w miejsce zasady dobrowolności wprowadzić prawny obowiązek przekazywania kopii archiwalnej, również dla określonych programów telewizyjnych produkowanych przez nadawców krajowych. Uzasadniając to stanowisko podkreślono,

${ }^{4}$ Dz. Urz. UE L 2001, Nr 167, str. 10. Na marginesie wypada zauważyć, że w myśl wyroku Trybunału Sprawiedliwości z dnia 24 listopada 2011 r. C - 70/10. Dyrektywy 2000/31 w sprawie niektórych aspektów prawnych usług społeczeństwa informacyjnego, w szczególności handlu elektronicznego w ramach rynku wewnętrznego 2001/29 w sprawie harmonizacji niektórych aspektów praw autorskich i pokrewnych w społeczeństwie informacyjnym, 95/46 w sprawie ochrony osób fizycznych w zakresie przetwarzania danych osobowych i swobodnego przepływu tych danych oraz 2002/58 dotycząca przetwarzania danych osobowych i ochrony prywatności w sektorze łączności elektronicznej pozostające w związku i interpretowane w świetle wymogów wynikających z ochrony mających zastosowanie praw podstawowych, należy rozumieć w ten sposób, że stoją one na przeszkodzie skierowanemu do dostawcy dostępu do Internetu nakazowi wdrożenia systemu filtrowania. Zob. Glosa aprobująca M. Górskiego, LEX/el 2012 i M. Kręcisz, LEX/el 2014 
że programy takie bardziej niż dzieła kinematograficzne odzwierciedlają płynność i dynamikę współczesnego życia społecznego i kulturalnego. W opinii podniesiono, że Europejski Komitet Ekonomiczno-Społeczny jest świadomy faktu, że nadawcy telewizyjni nie popierają koncepcji prawnego obowiązku przekazywania archiwalnych kopii programów. Mimo to zachęcano Komisję do bardziej wnikliwego zbadania tego problemu w drodze analiz sektorowych w celu ustalenia czy przynajmniej programy telewizyjne o największym znaczeniu społeczno - kulturalnym nie powinny podlegać obowiązkowi przekazywania kopii, gdyż - jak stwierdzono - stanowią one również element audiowizualnego dziedzictwa kultury.

W dalszej części opinii wywiedziono, że Europejski Komitet Ekonomiczno-Społeczny zgadza się z poglądem, że przemysł filmowy ma ogromny potencjał tworzenia miejsc pracy, $\mathrm{w}$ tym również $\mathrm{w}$ dziedzinie ochrony dorobku kinematograficznego. Wskazano, że jest to szczególnie dostrzegalne w odniesieniu do branży audiowizualnej „, obliczu bogactwa nośników” i środków nadawczych oraz wielkiego potencjału, jaki reprezentuje technologia cyfrowa. Wyrażono przy tym nadzieję, że wszelkiego rodzaju pomoc obejmie również wszystkie dzieła audiowizualne, ze szczególnym uwzględnieniem konkurencyjności tego sektora we wszystkich jego zróżnicowanych formach. Podkreślając konieczność prowadzenia odpowiednich szkoleń zauważono, że winny one obejmować sektor audiowizualny, w jak najszerszym zakresie a nie ograniczać się wyłącznie do sektora filmowego.

Zauważono, że Komitet zgadza się z Komisją, co do potrzeby dobrowolnego przekazywania do archiwów materiałów pomocniczych i promocyjnych, a także materiałów filmowych oraz dzieł kinematograficznych z lat ubiegłych, gdyż stanowią one ważną część europejskiego dziedzictwa audiowizualnego. Zdając sobie sprawę z faktu, że może tego rodzaju żądania mogą wiązać się z kosztami podkreślono w opinii, iż należy wypracować właściwe zachęty do gromadzenia wspomnianych materiałów oraz dążyć do wyposażenia właściwych organów w fundusze potrzebne do w miarę szybkiego utworzenia systematycznego zbioru materiału, odzwierciedlającego bogactwo tożsamości kulturowych w Europie, oraz różnorodność ich mieszkańców.

We wnioskach opinii Europejski Komitet Ekonomiczno-Społeczny wyraził przekonanie, że dla osiągnięcia głównych założonych celów Komisja powinna bezzwłocznie podjąć aktywne działania, a w szczególności ustalić tryb obowiązkowego przekazywania materiałów, umożliwiający wzajemne połączenie i współdziałania systemów krajowych oraz wspierać tworzenie europejskich norm katalogowania. Zwrócono także uwagę na konieczność zapewnienia zarówno technicznych, jak i prawnych warunków powstania odpowiednio zabezpieczonych i aktualizowanych w czasie rzeczywistym archiwów online, które w przyszłości stworzą podstawę europejskiej bazy danych. Podkreślono, że Komisja winna także zaproponować ogólnoeuropejski wzór umowy między właściwymi organami, deponentami materiałów oraz ewentualnie posiadaczami praw autorskich w celu ułatwienia konserwacji dzieł, a następnie ich udostępnianie dla celów badawczych i edukacyjnych. Taki europejski wzór umowy miał być zgodny z dyrektywą 2001/29/WE Parlamentu 
Europejskiego i Rady z 22 maja 2001 r. w sprawie harmonizacji niektórych aspektów praw autorskich i pokrewnych w społeczeństwie informacyjnym ${ }^{5}$. Europejski Komitet Ekonomiczno-Społeczny wskazał także na konieczność zdefiniowania we współpracy z właściwymi organami warunków publicznego udostępniania zdeponowanych dzieł. Wskazano jednocześnie, że Komisja winna wspierać współpracę między właściwymi organami na szczeblu krajowym i regionalnych w szczególności poprzez tworzenie odpowiednich struktur oraz pomoc finansową, jeśli takowa

${ }^{5}$ Dz. Urz. UE L 2001, Nr 167, str. 10. Zwrócić wypada szczególną uwagę na treść art. 5 wspomnianej dyrektywy odnoszącego się do problemu tymczasowych czynności zwielokrotnienia, mających charakter przejściowy lub dodatkowy a stanowiących integralną i podstawową część procesu technologicznego w celach wskazanych w ust. 1 tegoż artykułu. W kwestii tej zob. w odniesieniu do prasy drukowanej G. Pacek, Wykorzystywanie przez prasę utworów chronionych prawem autorskim, Warszawa 2013, rozdz. 3.3. Autor ten zwraca uwagę, że zgodnie z dyrektywą Parlamentu Europejskiego i Rady 2010/13/WE z 10 marca 2010 r. w sprawie koordynacji niektórych przepisów ustawowych wykonawczych i administracyjnych państw członkowskich dotyczących świadczeń audiowizualnych usług medialnych (dyrektywa o audiowizualnych usługach medialnych) Dz. Urz. UE L. 2010, Nr 95, str. 1 „, celu zagwarantowania podstawowej wolności pozyskiwania informacji oraz zapewnienia pełnej i należytej ochrony interesów widzów w Unii, właściciele wyłącznych praw do rozpowszechniania telewizyjnego wydarzenia budzącego duże zainteresowanie odbiorców powinni na uczciwych, rozsądnych i niedyskryminujących zasadach, z należytym uwzględnieniem praw wyłącznych, udzielać pozostałym nadawcom prawa do wykorzystywania krótkich fragmentów tych wydarzeń na użytek ogólnych audycji informacyjnych (...). Takie krótkie fragmenty mogą być - jak wskazano w dyrektywie wykorzystywana przez wszystkie kanały także przez specjalne kanały sportowe dla celów przekazu obejmującego obszar całej Unii Europejskiej i powinny trwać nie dłużej niż 90 sekund". Autor ten podkreślił, że cel korzystania ze wspomnianych krótkich fragmentów podobny jest do tego, o którym mowa w dyrektywie 2001/29/WE Parlamentu Europejskiego i Rady z dnia 22 maja 2001 r. w sprawie harmonizacji niektórych aspektów autorskich i pokrewnych $\mathrm{w}$ społeczeństwie informacyjnym. Podkreśla jednak, że preambuła wprowadza w punkcie 55 dodatkowe ograniczenie stanowiąc, że ,pojęcie ogólnych audycji informacyjnych nie powinny obejmować audycji skompilowanych z takich krótkich fragmentów i służących celom rozrywkowym". Adresatem wspomnianych norm jest przy tym jego zdaniem tylko dostawca tradycyjnych audiowizualnych usług medialnych, czyli telewizji z wyłączeniem wchodzących na rynek usług nielinearnych, o których mowa w punkcie 10 preambuły, czyli różnego rodzaju usług audiowizualnych na żądanie. Dodać należy, że w audiowizualnych usługach medycznych na żądanie krótkie fragmenty mogą być wykorzystywane jedynie w przypadku, gdy ten sam dostawca usług medialnych prezentuje tę samą audycję w czasie późniejszym. Zob. art. 15 ust. 2 dyrektywy Parlamentu Europejskiego i Rady 2010/13/UE z 10 marca 2010 r. w sprawie koordynacji niektórych przepisów ustawowych, wykonawczych i administracyjnych państw członkowskich dotyczących świadczenia audiowizualnych usług medialnych (dyrektywa o audiowizualnych usługach medialnych) Zob. w tym przedmiocie także K. Chałubińska - Jentkiewicz, M. Karpiuk, Prawo nowych technologii. Wybrane zagadnienia, Warszawa 2015, s. 127. Por. w tym przedmiocie wyroki Europejskiego Trybunału Sprawiedliwości: z 24 listopada 2011 r. w sprawie C - 281/09 Komisja v. Hiszpanii Zbiór Orzeczeń Trybunału Sprawiedliwości 2011, str. I - 11811; z 22 stycznia 2013 r. C - 283/11 w sprawie Sky Österreich GmbH v. Österreichischer Rundfunk Zbiór Orzeczeń Trybunału Sprawiedliwości 2013/1-/I-; Zob. Opinia Rzecznika Generalnego YVESA BOTA ECULI:EU:C - 2012: 341. W związku z powyższym zob. postanowienie Sądu Najwyższego z 15 maja 2014 r. III SK 28/13; OSNP 2015, Nr 10, poz. 143 
będzie potrzebna, a także wyznaczać wzorce na podstawie najlepszych praktyk i monitorować postępy za pomocą okresowych sprawozdań.

Europejski Komitet Ekonomiczno-Społeczny w przywoływanej opinii wyraził pogląd, że Komisja powinna odgrywać aktywną rolę w osiągnięciu celu, jakim winna być europejska filmografia audiowizualna, powinna także dążyć do wspólnej realizacji przedsięwzięć edukacyjnych i badawczych, zmierzać do archiwizacji dawnych dzieł realizowanych w nowych państwach członkowskich, gdyż te mają bogatą produkcję filmową stanowiącą świadectwo historii, kultury, sposobu życia oraz zwyczajów w tych państwach, której przetrwanie jest jednak zagrożone ze względu na szczupłość środków przeznaczonych na ten cel. Godzi się w tym miejscu zauważyć, że Europejski Komitet Ekonomiczno - Społeczny z jednej strony dostrzega interesujący dorobek filmowy stworzony w nowych państwach przyjętych do Unii, z drugiej jest świadom słabości środków, jakie te państwa mogą przeznaczyć na archiwizację dawnych dzieł w szczególności filmowych.

W opinii wskazano, że konieczne jest utworzenie odpowiedniej struktury umożliwiającej lepsze wykorzystanie funduszy będących w dyspozycji organów krajowych lub regionalnych promujących upowszechnienie produkcji filmowej w Europie i na świecie przy użyciu najnowocześniejszych metod medialnych (np. płyty DVD z napisami w kilku językach europejskich). Zdaniem Europejskiego Komitetu Ekonomiczno-Społecznego może to umożliwić „zarabianie na siebie” nawet dawnym utworom. Za właściwe uznano zwrócenie uwagi na tematy stanowiące przedmiot zainteresowania lub polityki wspólnoty np. takich jak ochrona dzieci lub wizerunek kobiety względnie konkretnych tradycji np. filmy animowane, filmy dla dzieci czy filmy dokumentalne. Podkreślono także, że konieczne jest ściąganie uwagi odbiorców na dzieła prezentowane na regionalnych lub lokalnych festiwalach tematycznych w celu promowania produkcji niezależnych, realizowanych przez reżyserów działających poza głównym nurtem komercyjnym, w razie konieczności przez obowiązek przekazywania kopii opinii archiwalnych. Za niezbędne uznano także promowanie szkolenia w dziedzinie konserwacji i rekonstrukcji filmów wymagającej wysokiego poziomu profesjonalizmu oraz stosowania nowych technik przez odpowiednie finansowanie ze środków wspólnotowych, najlepiej w ramach kolejne edycji programu MEDIA TRAINING ${ }^{6}$.

${ }^{6}$ W kwestii digitalizacji i rekonstrukcji cyfrowej filmów zob. J. Sobczak, M. Gołda-Sobczak, Digitalizacja i udostępnienie w Internecie dorobku kulturowego oraz ochrona zasobów cyfrowych, w: J. Sobczak, K. Chałubińska-Jentkiewicz, K. Kakareko (red.), „Prawo wobec kultury i sztuki”, Warszawa 2017 (w druku). Por. podstawowym dokumentem w zakresie digitalizacji jest obecnie wspominane już zalecenie Komisji z dnia 27 października 2011r. w sprawie digitalizacji i udostępniania w Internecie dorobku kulturowego oraz w sprawie ochrony zasobów cyfrowych, to jednak pamiętać należy, że zostało ono poprzedzone Rezolucją Rady C/162/02 z dnia 25 czerwca 2002r. w sprawie zachowania pamięci przyszłości - ochrona zasobów cyfrowych dla przyszłych pokoleń (Dz. Urz. UE C 2002, Nr 162, str. 4). Zalecenie Komisji z dnia 27 października 2011r. zostało poprzedzone także wcześniejszym zaleceniem Komisji z dnia 24 sierpnia 2006r. w sprawie digitalizacji i udostępniania w Internecie dorobku kulturowego oraz w sprawie ochrony zasobów 
W końcowej części opinii Europejski Komitet Ekonomiczno-Społeczny wyraził nadzieję, że w trwającej dyskusji nad programem MEDIA TRAINING w większej mierze uwzględniać się będzie szkolenie w zakresie nowych technologii oraz nowych wymogów dotyczących gromadzenia, katalogowania i rekonstrukcji utworów kinematograficznych oraz telewizyjnych, a także generalnie materiałów filmowych. Podkreślono że należy rozszerzać szkolenia w zakresie wykorzystania i znajomości nowych technik i metod archiwizowania, zarządzania bazami danych oraz znormalizowanych metod utrwalania utworów w wysokiej jakości formatach cyfrowych, wraz z kursami doszkalającymi dla operatorów tak, aby wyniki tych prac mogły być udostępniane jak najszerszej publiczności, w tym zwłaszcza naukowcom i nauczycielom. Wypada w tym miejscu zauważyć, że mimo iż Opinia Europejskiego Komitetu Ekonomiczno-Społecznego wydana została 15 września 2004 r., w Polsce niewiele na razie zrobiono aby spełnić oczekiwania wspomnianego Komitetu. Wypada żywić nadzieję, że nowopowstała instytucja Filmoteka Narodowa - Instytut Audiowizualny, utworzona z połączenia Narodowego Instytutu Audiowizualnego i Filmoteki Narodowej podejmie w tym względzie odpowiednie działania.

W motywach zalecenia Parlamentu Europejskiego i Rady z 16 listopada 2005 r. wskazano, że kinematografia jest formą sztuki zapisaną na nietrwałym nośniku, co wymaga odpowiednich działań ze strony władz publicznych w celu zapewnienia jej ochrony. Podkreślono, że utwory kinematograficzne są istotnym elementem dziedzictwa kulturowego, w związku z czym zasługują na szczególną i pełną ochronę. Wskazano że, niezależnie od wartości, którą wnoszą one do kultury, stanowią one źródło informacji historycznej o społeczeństwie europejskim. Dowodzą również

cyfrowych. Dz. Urz. UE L 2006, Nr 236, str. 28. Zalecenie to zostało poparte konkluzjami Rady w sprawie digitalizacji i udostępnienia dorobku kulturowego oraz w sprawie ochrony zasobów cyfrowych. Council Conclusions on the Digitisation and Online Accessibility of Cultural Material and Digital Preservation (Dz. Urz. UE C 297 z 7.12.2006 r., s. 1), http://eur-lex.europa.eu/LexUriServ/ LexUriServ.do?uri=OJ: C:2006:297:0001:0005: EN: PDF. Nieco wcześniej, bo w dniu 16 listopada 2005r. zostało wydane Zalecenie Parlamentu Europejskiego i Rady w sprawie dziedzictwa filmowego i konkurencyjności związanych z nim działań przemysłowych. Dz. Urz. UE L 2005, Nr 323, str. 57. Wydając wspomniane zalecenie uwzględniono opinię komitetu ekonomiczno-społecznego w sprawie propozycji zalecenia Parlamentu Europejskiego i Rady w sprawie dorobku filmowego oraz konkurencyjności związanej z nim działalności przemysłowej (Dz. Urz. UE C 2005, Nr 74, str. 18). Pamiętać należy, że we wnioskach wspomnianej opinii wskazywano, że Komisja winna podjąć działania w celu utworzenia europejskiej filmografii audiowizualnej starać się o umożliwienie archiwizacji dawnych dzieł, zwłaszcza nowych państw członkowskich, utworzyć odpowiednią strukturę umożliwiającą lepsze wykorzystanie funduszy pozwalających na utrwalaniu przy użyciu najnowocześniejszych metod multimedialnych utworów państw członkowskich. W rezolucji Rady z 26 czerwca 2000r. w sprawie zachowania i podniesienia wartości dziedzictwa kina europejskiego wezwano państwa członkowskie do współpracy w restaurowaniu i konserwowaniu dziedzictwa kinematograficznego m.in. przez odwołanie się do technologii cyfrowych, do wymiany dobrych praktyk w tym sektorze, do propagowania stopniowego tworzenia europejskich sieci danych archiwalnych oraz do rozważenia możliwości wykorzystywania tych zbiorów w celach edukacyjnych (Dz. Urz. UE C 2000, Nr 193, str. 1). 
bogactwa tożsamości kulturowych Europy oraz różnorodności zamieszkujących ją ludzi. Uznano, że obrazy kinematograficzne stanowią zasadniczy element procesu poznawania przyszłości i są podstawą dla obywatelskiej refleksji nad cywilizacją europejską. Wywiedziono także w motywach, że celem Zalecenia jest wsparcie lepszego wykorzystania przemysłowego i kulturowego potencjału europejskiego dziedzictwa filmowego poprzez wspieranie polityk innowacyjności, badań i rozwoju technologicznego w dziedzinie konserwacji i restaurowania utworów kinematograficznych. Zmierza ono także do zapewnienia warunków niezbędnych dla konkurencyjności przemysłu filmowego wspólnoty. Podkreślono że dziedzictwo kulturowe stanowi istotny element przemysłu filmowego, a propagowanie jego konserwacji, restaurowania i eksploatacji może przyczynić się do poprawy konkurencyjności tego przemysłu. Rozwój europejskiego przemysłu filmowego ma - jak wskazano w motywach zalecenia - istotne znaczenie dla Europy ze względu na jego znaczący potencjał w dziedzinie dostępu do kultury, rozwoju gospodarczego i tworzenia miejsc pracy. Wskazano przy tym, że przemysł filmowy to nie tylko produkcja i projekcja filmów, ale również ich gromadzenie, katalogowanie, zachowanie i restaurowanie. Zauważono że konieczne jest poprawienie warunków konkurencyjności działalności przemysłowej związanej z dziedzictwem filmowym, w szczególności w zakresie lepszego wykorzystania osiągnięć technologicznych, zwłaszcza możliwości jakie daje digitalizacja.

Koniecznym jest - jak wskazano w Zaleceniu - powstanie sprawnego i innowacyjnego przemysłu filmowego Wspólnoty. Można do tego doprowadzić przez poprawę warunków konserwacji, restaurowania i eksploatacji dziedzictwa filmowego, a także usunięcie przeszkód w rozwoju i pełną konkurencyjność branży filmowej, w szczególności poprzez gromadzenie, katalogowanie, zachowanie i restaurowanie dziedzictwa filmowego oraz udostępnianie go do użytku oświatowego, kulturalnego, badawczego lub dla innych niekomercyjnych zastosowań o podobnym charakterze. Wskazano jednak, że winno się to dziać zawsze z poszanowaniem praw autorskich i praw pokrewnych. Podkreślenie tego elementu wydaje się bardzo istotne, gdyż w warunkach polskich istnieje duży nacisk różnych środowisk zmierzających, mniej lub bardziej otwarcie, do ograniczenia autorskich praw majątkowych, a nawet osobistych. U podstaw tych dążeń leży przekonanie, że twórcy, także filmowi, zostali „wykształceni przez społeczeństwo”, a więc winni spłacić zaciągnięty w ten sposób dług przenosząc swoje prawa do domeny publicznej.

W motywach zauważono, że konkurencyjność przemysłu filmowego poprawi się dzięki tworzeniu warunków współpracy między organami i instytucjami, którymi

${ }^{7}$ Zob. w tym przedmiocie J. Sobczak, Otwarte zasoby. Miraże wolności wobec gorsetu prawa, w: J. Sobczak, K. Chałubińska-Jentkiewicz, K. Kakareko (red.), „Biblioteki i archiwa na jednolitym rynku cyfrowym”, Poznań 2017 (w druku); J. Sobczak, M. Gołda-Sobczak, Wykorzystywanie utworów w dydaktyce. Między otwartymi zasobami edukacyjnymi a dozwolonym użytkiem publicznym, w: W. Lis, G. Tylec (red.), „Działalność naukowo-dydaktyczna w świetle prawa autorskiego”, Lublin 2015, s. 107-130. 
winny być europejskie, krajowe bądź regionalne archiwa, instytuty filmowe oraz podobne instytucje w sprawach dotyczących konserwacji i ochrony dziedzictwa filmowego. Przywołano przy tej okazji rezolucję Rady z 26 czerwca 2000 r. w sprawie zachowania i podniesienia wartości dziedzictwa kina europejskiego ${ }^{8}$, w której wezwano państwa członkowskie do współpracy w restaurowaniu i konserwacji dziedzictwa kinematograficznego m.in. poprzez odwołanie się do technologii cyfrowych, do wymiany dobrych praktyk w tym sektorze oraz do propagowania stopniowego tworzenia europejskich sieci danych archiwalnych, a także do rozważenia możliwości wykorzystania tych zbiorów w celach edukacyjnych.

W dalszej części motywów przywołano Europejską Konwencję w sprawie ochrony dziedzictwa audiowizualnego ${ }^{9}$, wskazując że stanowi ona, że każde państwo będące stroną konwencji musi wprowadzić za pomocą środków ustawodawczych lub innych właściwych środków obowiązek deponowania materiałów filmowych stanowiących część jej dziedzictwa audiowizualnego, wyprodukowanych lub koprodukowanych na terytorium danej strony. Przypomnieć należy, że celem Konwencji o ochronie dziedzictwa audiowizualnego - dzisiaj już dość mocno zapomnianej w literaturze - była chęć osiągnięcia większej spójności między państwa członkowskimi Rady Europy, w szczególności przez ochronę i rozwijanie wartości stanowiących „wspólne dziedzictwo”, odzwierciedlające „kulturalną identyfikację i zróżnicowanie ludzi”. W Konwencji wskazano, że istotnym współcześnie elementem takiego dziedzictwa jest film, będący wyrazem nie tylko ekspresji artystycznej, ale także odzwierciedlający życie europejskiego społeczeństwa. Podkreślono, że stanowi on podstawę dla badań naukowych oraz źródło refleksji nad współczesną cywilizacją. W treści Konwencji stwierdzono, że celem jej jest zapewnienie ochrony europejskiego dziedzictwa audiowizualnego i jego uznania zarówno jako formy twórczości artystycznej, jak i przekaz utrwalający przeszłość (art. 1 Konwencji). Dlatego też uznano za konieczne podjęcie działań zmierzających do gromadzenia, ochrony i udostępniania materiałów audiowizualnych dla celów kulturalnych, naukowych i badawczych w szeroko rozumianym interesie publicznym. Z treści Konwencji wynika, że ma ona zastosowanie do wszystkich dzieł kinematograficznych. Przewidziano przy tym, że po przyjęciu protokołów, określonych w treści art. 18 Konwencji, będzie miała ona także zastosowanie do dzieł audiowizualnych innych, niż produkcja kinematograficzna, w tym także do produkcji telewizyjnej. Zawarowano również, że przepisy Konwencji nie naruszają postanowień międzynarodowych traktatów dotyczących praw autorskich i praw pokrewnych (art. 4 Konwencji).

${ }^{8}$ Dz. Urz. UE C 2000, Nr 193, str. 1

${ }^{9}$ Konwencja ta została przyjęta przez Komitet Ministrów Rady Europy 19 września $2001 \mathrm{r}$. W literaturze bywa ona mylona z Konwencją w sprawie ochrony światowego dziedzictwa kulturalnego i naturalnego, uchwaloną przez UNESCO podczas 17. sesji w Paryżu 16 listopada 1972 r., weszła w życie z dniem 17 grudnia 1975 r., a do sierpnia 2016 r. przyjęta bądź ratyfikowana została przez 192 państwa. Polska ratyfikowała ją 6 maja 1976 r. Dz. U. 1976, Nr 32, poz. 190. 
W treści Konwencji zobowiązano państwa będące jej stronami do zorganizowania depozytów materiałów filmowych, stanowiących część ich audiowizualnego dziedzictwa, które zostały wyprodukowane lub współprodukowane na terytorium tego państwa. Przewidziano możliwość zwolnienia z tego obowiązku wówczas, gdy materiał taki został już zdeponowany w innym państwie będącym stroną Konwencji. Ponadto na państwa nałożono obowiązek wyznaczenia archiwów, w których chronione, dokumentowane, restaurowane i udostępniane materiały filmowe. Wskazano że takie archiwa mogą prowadzić jednostki państwowe lub prywatne, ale nie mogą być one powiązane lub zaangażowane finansowo w działalność przynoszącą zysk w sektorze mediów (art. 6 Konwencji). Przewidziano także możliwość tworzenia dobrowolnych depozytów materiałów, stanowiących część dziedzictwa audiowizualnego, nieobjętych zakresem rzeczowym art. 5 Konwencji.

Dopuszczono możliwość tworzenia przez państwa, będące stronami konwencji wspólnych organizacji archiwalnych i dobrowolnych depozytów (art. 13 Konwencji). W kolejnym przypisie określono szczegółowe formy współdziałania takich ciał. Stwierdzono przy tym, że będzie to służyć lepszej wymianie informacji o istniejących zasobach, wypracowaniu standardowej procedury w zakresie przechowywania materiałów, wreszcie określeniu wspólnych standardów dla wymiany informacji elektronicznej oraz konserwacji sprzętu audiowizualnego ${ }^{10}$.

Porównanie treści Konwencji funkcjonującej w ramach systemu Rady Europy z omawianym w tym miejscu zaleceniem Parlamentu Europejskiego i Rady z 16 listopada 2005 r. oraz rezolucjami Rady z 26 czerwca 2000 r. w sprawie zachowania i podniesienia wartości dziedzictwa kina europejskiego oraz rezolucją Rady z 24 listopada 2003 r. w sprawie deponowania utworów kinematograficznych w Unii Europejskiej ${ }^{11}$, wskazuje na daleko idącą zbieżność tekstu wspomnianej Konwencji z przywołanymi późniejszymi dokumentami systemu Unii Europejskiej.

Przypomniano w dalszej części motywów komunikat Komisji z 26 września 2001 r. w sprawie niektórych aspektów prawnych dotyczących utworów kinematograficznych oraz innych utworów audiowizualnych ${ }^{12}$, w którym, jak stwierdzono, przeanalizowano prawne deponowanie utworów audiowizualnych na poziomie krajowym i regionalnym jako jeden z możliwych sposobów konserwacji i ochrony europejskiego dziedzictwa audiowizualnego. Zauważono że wspomniany komunikat rozpoczął przegląd sytuacji dotyczącej deponowania utworów kinematograficznych w państwach członkowskich. W motywach wskazano także, że Rada ds. kultury

${ }^{10} \mathrm{~W}$ kwestii treści Konwencji zob. J. Sobczak, Europejski ład komunikacyjny w procesie globalizacji, w: J. Sobczak, R. Bäcker (red.), „Europejska myśl polityczna wobec globalizacji. Tradycja i wyzwania współczesności”, Łódź 2005, s. 39-69; A. Jaskiernia, Rada Europy a problemy mediów masowych, Warszawa 2002, s. 77-79.

${ }^{11}$ Dz. Urz. UE C 2003, Nr 295, str. 5.

${ }^{12}$ Dz. Urz. UE C 2002, Nr 43, str. 6. Zob. także stanowisko rządu RP w sprawie „Zielonej Księgi dotyczącej dystrybucji utworów audiowizualnych w Unii Europejskiej. Możliwości i wyzwania związane z jednolitym rynkiem cyfrowym". 
i środków audiowizualnych na posiedzeniu w dniu 5 listopada 2001 r. przychylnie przyjęła komunikat Komisji z 26 września 2001 r.

W dalszej części motywów przywołano rezolucję Parlamentu Europejskiego z 2 lipca 2002 r. w sprawie komunikatu Komisji z 26 września 2001 r. ${ }^{13}$, w której podkreślono znaczenie ochrony dziedzictwa kinematograficznego, popierając stanowisko wyrażone w Europejskiej konwencji o ochronie dziedzictwa audiowizualnego, uznając że stanowi ona ważny punkt odniesienia w czasach nasilonych zmian technologicznych. Wskazano że stopniowe przechodzenie na techniki cyfrowe umożliwi większą konkurencyjność europejskiego przemysłu filmowego i w dłuższym okresie przyczyni się do zmniejszenia kosztów katalogowania, deponowania, konserwacji i restaurowania utworów audiowizualnych, jednocześnie stworzy nowe możliwości innowacji w dziedzinie ochrony dziedzictwa filmowego. Przypomniano w końcowej części motywów, że rezolucja Rady z 24 listopada 2003 r. w sprawie deponowania utworów kinematograficznych w Unii Europejskiej ${ }^{14}$, zachęcała państwa członkowskie do wdrożenia skutecznego systemu deponowania i zachowania utworów kinematograficznych stanowiących część ich dziedzictwa audiowizualnego w swoich archiwach krajowych, instytucjach filmowych lub podobnych instytucjach - jeżeli takie systemy jeszcze nie istnieją. Wskazano, że wszystkie państwa członkowskie posiadają już systemy gromadzenia i zachowania utworów kinematograficznych, stanowiących część ich dziedzictwa audiowizualnego. Uznano, że 4/5 tych systemów opiera się na zobowiązaniu prawnym lub umownym do deponowania wszystkich filmów lub przynajmniej filmów, które otrzymały finansowanie publiczne. Podkreślono, że w celu zapewnienia, że europejskiej dziedzictwo filmowe zostanie przekazane przyszłym pokoleniom, należy je w sposób metodyczny gromadzić, katalogować, zachowywać i restaurować w każdym przypadku w zgodności z prawami autorskimi i pokrewnymi. Europejskie dziedzictwo filmowe winno być bardziej dostępne dla celów edukacyjnych, kulturalnych, badawczych lub innych niekomercyjnych zastosowań o podobnym charakterze, przy czym w każdym przypadku w zgodności z prawami autorskimi i pokrewnymi. Podkreślono także, że przeniesienie egzemplarzy utworów kinematograficznych na organy archiwizujące nie oznacza przeniesienia praw autorskich i praw pokrewnych. Wskazano na koniec, że treść art. 5 ust. 2 lit. c) dyrektywy 2001/29/WE Parlamentu Europejskiego i Rady z dnia 22 maja 2001 r. w sprawie harmonizacji niektórych aspektów praw autorskich i pokrewnych w społeczeństwie informacyjnym ${ }^{15}$ stanowi że państwa członkowskie mogą przewidzieć wyjątki lub ograniczenia w odniesieniu do szczególnych czynności reprodukowania dokonywanych przez ogólnodostępne biblioteki lub przez archiwa, które nie

${ }_{13}$ Dz. Urz. UE C 2003, Nr 271, str. 176.

${ }^{14}$ Dz. Urz. UE C 2003, Nr 295, str. 5.

15 Dz. Urz. UE L 2001, Nr 167, str. 10. Por. K. Chałubińska-Jentkiewicz, M. Karpiuk, Prawo nowych technologii. Wybrane zagadnienia, Warszawa 2015, s. 179 i n. oraz s. 191 i n. 
mają na celu osiągnięcia bezpośredniej lub pośredniej korzyści gospodarczej lub handlowej.

Wyjaśniono w końcu w motywach zalecenia, że przez „materiał filmowy” należy rozumieć każdy zapis filmowy, niezależnie od tego jakimi środkami i na jakim nośniku został zarejestrowany, z dźwiękiem lub bez, zdolny przekazać wrażenie ruchu. Pod pojęciem „utworu kinematograficznego” Zalecenie chce rozumieć dowolnej długości materiał filmowy, w szczególności filmy fabularne, filmy rysunkowe i filmy dokumentalne, przeznaczone do wyświetlania w kinach. „Utwory kinematograficzne stanowiące część dziedzictwa audiowizualnego" oznaczają produkcje filmowe, w tym koprodukcje z innymi państwami członkowskimi lub państwami trzecimi, zaklasyfikowane jako takie przez państwa członkowskie lub wskazane przez nie organy w oparciu o obiektywne, przejrzyste i niedyskryminujące kryteria. Całość dziedzictwa audiowizualnego państw członkowskich stanowi europejskie dziedzictwo audiowizualne.

W Zaleceniu wskazano, że Parlament Europejski i Rada Unii Europejskiej przyjmują do wiadomości zamiar Komisji aby rozważyć wprowadzenie obowiązku deponowania w archiwum przynajmniej jednego państwa członkowskiego filmów europejskich, które otrzymały finansowanie ze środków Unii Europejskiej. Podkreśliła Komisja także potrzebę wsparcia współpracy pomiędzy wyznaczonymi organami państw członkowskich. Zaznaczono ponadto potrzebę wypracowania systemu finansowania projektów badawczych w dziedzinach długookresowego zachowywania i restaurowania filmów. Za niezbędne uznano promowanie wprowadzenia wspólnych norm w zakresie katalogowania filmów przez współfinansowanie projektów normalizacji i przez wzmocnienie wymiany najlepszych praktyk, przy jednoczesnym poszanowaniu różnorodności językowej. Wskazano potrzebę podjęcia działań na rzecz ułatwienia negocjacji dotyczących standardowych umów na poziomie europejskim pomiędzy wyznaczonymi organami a posiadaczami praw, określającej warunki, na których wyznaczone organy mogą udostępniać publicznie zdeponowane utwory kinematograficzne. Komisja zawarowała prawo monitorowania oraz oceny stopnia, w jakim środki określone w Zaleceniu są skuteczne oraz rozważenia konieczność podjęcia dalszych działań.

Zalecono także, aby państwa członkowskie poprawiły warunki konserwacji, restaurowania i korzystania z dziedzictwa filmowego oraz usunęły przeszkody na drodze do rozwoju i pełnej konkurencyjności europejskiego przemysłu filmowego. Cel ten winny osiągnąć przez wspieranie zwiększonego wykorzystania potencjału przemysłowego i kulturalnego europejskiego dziedzictwa filmowego przy pomocy środków systematycznej konserwacji i restaurowania, zachęcając do polityk innowacji, badań i rozwoju technicznego w dziedzinie konserwacji i restaurowania utworów kinematograficznych. Państwa członkowskie na mocy Zalecenia zostały zobowiązany do podjęcia w terminie do 16 listopada 2007 r. środków ustawodawczych, administracyjnych lub innych właściwych środków w celu zapewnienia, aby utwory kinematograficzne stanowiące część ich dziedzictwa audiowizualnego 
były systematycznie gromadzone, katalogowane, zachowywane, rekonstruowane i udostępniane do użytku oświatowego, kulturalnego, badawczego lub dla innych niekomercyjnych zastosowań o podobnym charakterze, w każdym przypadku w zgodności z prawami autorskimi i pokrewnymi. Warunkiem podjęcia powyższych działań stało się wyznaczenie odpowiednich organów do ich realizacji w interesie publicznym w sposób niezależny i profesjonalny, zapewniając im otrzymanie najlepszych dostępnych zasobów finansowych i technicznych. Organy, które państwa członkowskie zobowiązane zostały wyznaczyć do realizacji wspomnianych zadań, powinny być zachęcane przez państwa członkowskie, do określenia, w porozumieniu lub w drodze umowy z posiadaczami praw, warunków, na jakich zdeponowane utwory kinematograficzne mogą być udostępniane publiczności. W celu promowania dziedzictwa filmowego, za niezbędne uznano ustanowienie lub wspieranie krajowych akademii filmowych lub podobnych podmiotów. Komisja podkreśliła, że państwa członkowskie winny podjąć działania oraz wszelkie niezbędne środki w celu zwiększenia wykorzystania technologii cyfrowych i nowych technologii do gromadzenia, katalogowania, zachowania i restaurowania utworów kinematograficznych.

W zakresie gromadzenia uznano za konieczne podjęcie systematycznego gromadzenia utworów kinematograficznych stanowiących część ich narodowego dziedzictwa audiowizualnego $\mathrm{w}$ drodze obowiązkowego prawnego lub umownego depozytu w wyznaczonych organach, co najmniej jednej wysokiej jakości kopii takich utworów kinematograficznych. Wyznaczając warunki deponowania, państwa członkowskie powinny zagwarantować, że w okresie przejściowym obejmują one te produkcje lub koprodukcje, które otrzymały publiczne finansowanie na poziomie krajowym lub regionalnym. Po upływie wspomnianego okresu przejściowego warunki deponowania powinny obejmować, tak dalece, jak to praktycznie możliwe, wszystkie produkcje, w tym produkcje, które nie otrzymały żadnego publicznego finansowania. Ponadto zdeponowane utwory kinematograficzne powinny być dobrej jakości technicznej, tak aby ułatwić ochronę i możliwość powielania, a towarzyszące metadane winny mieć standardową formę, stosownie do okoliczności. Film powinien zostać złożony do depozytu w momencie publicznego udostępnienia filmu, a w żadnym przypadku nie później niż w ciągu dwóch lat.

Określono także działania w zakresie katalogowania i tworzenia baz danych. Wskazano, że konieczne jest przyjęcie odpowiednich środków przyjęcie odpowiednich środków, które mogłyby ostatecznie doprowadzić do powstania kodeksu archiwizacji produkcji filmowej, w celu promowania katalogowania i indeksowania zdeponowanych utworów kinematograficznych oraz zachęcenia do tworzenia baz danych zawierających informacje o filmach, przy użyciu europejskich i międzynarodowych norm. Ponadto za niezbędne uznano promowanie normalizacji europejskiej, interoperacyjności filmograficznych baz danych i ich dostępności dla społeczeństwa, na przykład poprzez Internet, szczególnie przez aktywne zaangażowanie wyznaczonych organów. Podkreślono także potrzebę stworzenia 
sieci baz danych obejmującej europejskie dziedzictwo audiowizualne, we współpracy z odpowiednimi organizacjami, w szczególności Radą Europy (Eurimages i Europejskie Obserwatorium Audiowizualne). Jako jeden z nadrzędnych celów wskazano zachęcanie organów zajmujących się archiwizacją do zwiększenia wartości zasobów poprzez organizowanie ich w zbiory na poziomie UE, na przykład pod względem tematu, autora i okresu.

Odnosząc się do działań w zakresie zachowania, uznano za konieczne przyjęcie ustawodawstwa lub wykorzystanie innych metod zgodnie z krajowymi praktykami w celu zapewnienia zachowania zdeponowanych utworów kinematograficznych. Środki służące zachowaniu powinny obejmować w szczególności reprodukowanie filmów na nowych nośnikach danych, a także zachowanie sprzętu przeznaczonego do projekcji utworów kinematograficznych na różnych nośnikach. W odniesieniu do restaurowania wskazano za konieczne wprowadzenie wszystkich właściwych środków w celu zezwolenia, w ramach swojego ustawodawstwa, na reprodukowanie zdeponowanych utworów kinematograficznych dla celów restaurowania, jednocześnie umożliwiając posiadaczom praw korzystanie, na podstawie umów między wszystkimi zainteresowanymi stronami, z udoskonalonego potencjału przemysłowego ich utworów, będącego wynikiem restaurowania. Zaznaczono także potrzebę wsparcia dla projektów restaurowania starych filmów lub filmów o wysokiej wartości kulturalnej lub historycznej.

W kwestii udostępniania zdeponowanych utworów kinematograficznych w Zaleceniu uznano za konieczne przyjęcie środków ustawodawczych lub administracyjnych w celu umożliwienia wyznaczonym organom udostępniania zdeponowanych utworów kinematograficznych do użytku oświatowego, kulturalnego, badawczego lub dla innych niekomercyjnych zastosowań o podobnym charakterze, w każdym przypadku w zgodności z prawami autorskimi i pokrewnymi. Zakreślono potrzebę podjęcia przez państwa członkowskie odpowiednich środków w celu zapewnienia osobom niepełnosprawnym dostępu do zdeponowanych utworów kinematograficznych, w każdym przypadku w zgodności z prawami autorskimi i pokrewnymi.

Przewidziano także podjęcie działań w zakresie szkolenia zawodowego i znajomości mediów, uznając za konieczne promowanie szkolenia zawodowego we wszystkich dziedzinach związanych z dziedzictwem filmowym w celu wspierania zwiększonego wykorzystania przemysłowego potencjału dziedzictwa filmowego. Odnotowano potrzebę promowania wykorzystania dziedzictwa filmowego do wzmocnienia wymiaru europejskiego w zakresie edukacji i propagowania różnorodności kulturowej. W celu realizacji założeń Zalecenia z niezmiernie ważne uznano wspieranie i propagowanie edukacji wizualnej, filmoznawstwa i umiejętności korzystania z mediów na wszystkich poziomach edukacji, w programach kształcenia zawodowego i w programach europejskich. Do zadań państwo członkowskich we wspomnianym zaliczono promowanie bliskiej współpracy między producentami, dystrybutorami, nadawcami i instytutami filmowymi dla celów edukacyjnych, przy jednoczesnym poszanowaniu kwestii praw autorskich i pokrewnych. 
Szczegółowo uregulowano kwestie odnoszące się do depozytu, proponując rozważenie stworzenia systemu dobrowolnego lub obowiązkowego deponowania materiałów towarzyszących i reklamowych związanych z utworami kinematograficznymi stanowiącymi część narodowego dziedzictwa audiowizualnego. Ponadto do depozytów winny trafić, zgodnie z założeniami Zalecenia, utwory kinematograficzne stanowiące część narodowego dziedzictwa audiowizualnego z innych krajów oraz materiały zawierające ruchome obrazy inne niż utwory kinematograficzne, a także utwory kinematograficznych wyprodukowanych w przeszłości.

Określono zasady współpracy organów wyznaczonych do wymiany informacji i koordynowania ich działalności na poziomie krajowym i europejskim, wskazując przykładowo zapewnienia spójności metod gromadzenia i konserwacji oraz interoperacyjności baz danych. W ramach współpracy wspomniane wyznaczone organy winny wypracować zasady wydawania, na przykład na DVD, materiałów archiwalnych z napisami w możliwie największej liczbie języków Unii Europejskiej, w każdym przypadku w zgodności z prawami autorskimi i pokrewnymi oraz zbierania europejskiej filmografii, a także tworzenia wspólnego standardu dla elektronicznej wymiany informacji. Organy te mają przygotowywać wspólnych projektów badawczych i edukacyjnych, promując jednocześnie rozwój europejskich sieci szkół filmowych i muzeów kina.

Uznano także za konieczne aby państwa członkowskie UE informowały Komisję co 2 lata o podjętych działaniach w zakresie określonym przez Zalecenie. W dniu 15 listopada 2013 r. Komisja wydała komunikat w sprawie pomocy państwa przeznaczonej na filmy i inne utwory audiowizualne ${ }^{16}$. W Komunikacie przypomniano, że kryteria oceny pomocy państwa w przypadku produkcji filmów i innych utworów audiowizualnych zostały pierwotnie określone w komunikacie w sprawie kinematografii z $2001 \mathrm{r}^{17}$. Wspomniano, że obowiązywanie tych kryteriów zostało przedłużone w 2004 r. ${ }^{18}, 2007$ r. ${ }^{19}$ oraz 2009 r. ${ }^{20}$, a wygasło w dniu 31 grudnia 2012 r. W niniejszym komunikacie utrzymano główne kierunki komunikatu z 2001 r. przy jednoczesnym uwzględnieniu szeregu tendencji, które pojawiły się od 2001 r. W Komunikacie wprowadzono zmiany do kryteriów określonych w komunikacie z $2001 \mathrm{r}$. Wspomniane zmiany dotyczył przede wszystkim pomocy państwa dla szerszego zakresu działań. Podkreślono znaczenie zasady pomocniczości w dziedzinie polityki kulturalnej oraz przestrzegania zasad rynku wewnętrznego. Wprowadzono wyższy dopuszczalny poziom intensywności pomocy dla produkcji transgranicznych oraz przewidziano działania na rzecz ochrony dziedzictwa filmo-

16 Dz. Urz. UE C 2013, Nr 332, str. 1

${ }^{17}$ Komunikat Komisji do Rady, Parlamentu Europejskiego, Europejskiego Komitetu Ekonomiczno-Społecznego i Komitetu Regionów w sprawie niektórych aspektów prawnych dotyczących produkcji kinematograficznych i innych produkcji audiowizualnych, Dz. Urz. UE C 2002, Nr 43, str. 6

18 Dz. Urz. UE C 2004, Nr 123, str. 1.

19 Dz. Urz. UE C 2007, Nr 134, str. 5.

${ }^{20}$ Dz. Urz. UE C 2009, Nr 31, str. 1 
wego i dostępu do niego. Komisja wskazała, że zmiany te są niezbędne w związku z rozwojem sytuacji od 2001 r., że przyczynią się one do zwiększenia konkurencyjności europejskich produkcji oraz spowodują, że będą one w większym stopniu paneuropejskie. Kwestie opisane w komunikacie oraz ich wdrażanie zasługują na szersze rozważenie w odrębnym artykule.

\section{BIBLIOGRAFIA}

Chałubińska - Jentkiewicz, K., Karpiuk M., Prawo nowych technologii. Wybrane zagadnienia, Warszawa 2015.

Jaskiernia A., Rada Europy a problemy mediów masowych, Warszawa 2002.

Komunikat Komisji do Rady, Parlamentu Europejskiego, Europejskiego Komitetu Ekonomiczno-Społecznego i Komitetu Regionów w sprawie niektórych aspektów prawnych dotyczących produkcji kinematograficznych i innych produkcji audiowizualnych, Dz. Urz. UE C 2002, Nr 43.

Pacek G., Wykorzystywanie przez prasę utworów chronionych prawem autorskim, Warszawa 2013.

Sanetra W., w: A. Wróbel (red.) Traktat o funkcjonowaniu Unii Europejskiej. Komentarz, t. II, Warszawa 2012.

Sobczak J., Gołda-Sobczak M., Digitalizacja i udostepnienie w Internecie dorobku kulturowego oraz ochrona zasobów cyfrowych, w: J. Sobczak, K. Chałubińska-Jentkiewicz, K. Kakareko (red.), Prawo wobec kultury i sztuki, Warszawa 2017 (w druku).

Sobczak J., Gołda-Sobczak M., Wykorzystywanie utworów w dydaktyce. Między otwartymi zasobami edukacyjnymi a dozwolonym użytkiem publicznym, w: W. Lis, G. Tylec (red.), Działalność naukowo-dydaktyczna w świetle prawa autorskiego, Lublin 2015.

Sobczak J., Europejski ład komunikacyjny w procesie globalizacji, w: J. Sobczak, R. Bäcker (red.), Europejska myśl polityczna wobec globalizacji. Tradycja i wyzwania współczesności, Łódź 2005.

Sobczak J., Otwarte zasoby. Miraże wolności wobec gorsetu prawa, w: J. Sobczak, K. Chałubińska-Jentkiewicz, K. Kakareko (red.), Biblioteki i archiwa na jednolitym rynku cyfrowym, Poznań 2017 (w druku).

\section{Streszczenie}

Dziedzictwo filmowe stanowi coraz obszerniejszą grupę materiałów, które niestety nie mają jednolitych regulacji dotyczących ich gromadzenia, konserwacji i udostępniania. Artykuł przybliża pracę nad kolejnymi dokumentami Unii Europejskiej, regulującymi zagadnienia związane z utworami filmowymi oraz audiowizualnymi. Ukazane zostały wypracowane standardy dotyczące spójności metod gromadzenia i konserwacji oraz interoperacyjności baz danych zawierających utwory audiowizualne.

Słowa kluczowe: prawo filmowe, dziedzictwo filmowe, utwory audiowizualne, kinematografia. 


\section{FILM HERITAGE IN EUROPEAN UNION LAW}

\section{Sum mary}

Film heritage is an ever-expanding group of materials. Unfortunately, they do not have uniform regulations for their collection, maintenance and sharing. This article shows the course of work on subsequent European Union documents regulating issues related to film and audiovisual works. This article presents the standards developed by the European Union concerning the consistency of methods of collection, maintenance and interoperability of databases containing audiovisual works.

Keywords: film law, film heritage, audiovisual works, cinematography. 